\title{
Migration and Memorials: Irish Cultural Identity in Early Nineteenth-Century Lowell, Massachusetts
}

\section{Colm Donnelly $^{1} \cdot$ Eileen Murphy $^{1} \cdot$ Dave McKean $^{2} \cdot$ Lynne McKerr $^{3}$}

Published online: 18 December 2019

(C) The Author(s) 2019

\begin{abstract}
Lowell is considered as the birthplace of the industrial revolution in the early nineteenth-century United States. Originating in 1822, the new textile factories harnessed the waters of the Merrimack River using a system of canals, dug and maintained by laborers. While this work employed many local Yankees, it also attracted groups of emigrant Irish workers. Grave memorials are a valuable source of information concerning religious and ethnic identity and an analysis of the slate headstones contained within Yard One of St Patrick's Cemetery, opened in 1832, provides insight into the mindset of this migrant community. The headstones evolved from contemporary Yankee memorials but incorporated Roman Catholic imagery, while the inclusion of shamrocks and details of place of origin on certain memorials attests to a strong sense of Irish identity. The blatant display of such features at a time of ethnic and religious sectarian tensions in Massachusetts demonstrates the confidence that the Irish had of their place in the new industrial town.
\end{abstract}

Keywords Irish-America - Shamrocks · Ethnicity - Chain migration · Industrial revolution · Catholicism

Colm Donnelly

c.j.donnelly@qub.ac.uk

Eileen Murphy

eileen.murphy@qub.ac.uk

Dave McKean

dadumc@comcast.net

Lynne McKerr

1.mckerr@qub.ac.uk

1 Archaeology and Palaeoecology, School of Natural and Built Environment, Queen's University Belfast, Belfast BT7 1NN, Northern Ireland

2 Lowell, Massachusets, USA

3 Centre for Behaviour Analysis, School of Social Sciences, Education and Social Work, Queen's University Belfast, Belfast BT7 1NN, Northern Ireland 


\section{Introduction: Irish Pioneers in Lowell}

Regarded as the birthplace of the industrial revolution in the US, and a National Park since 1979, Lowell in Middlesex County, Massachusetts, originated in 1822 as a planned manufacturing center for textile production (Fig. 1). This was a green-field development on what had been the Yankee farmlands of East Chelmsford and was the creation of the Boston Associates, a group of entrepreneurs, merchants, and industrialists led by Francis Cabot Lowell (1775-1817), after whom the new manufacturing center was named (Dublin 1992: 30-33). The location chosen by the Boston Associates for their development was the confluence of the River Merrimack and the River Concord in order to take advantage of the water to run waterwheels within factories; canals, however, would be required to bring the water to the millwheels and these were dug and maintained by laborers. While this work employed many local Yankees, it also attracted migrant Irish workers.

A note contained in the Lowell Morning Times on April 19, 1886, recounted the recollections of "a lady subscriber" and detailed how the first Irish residents of the area came in 1819 and comprised six families and a single man who had come across from Ireland on a ship called the Elizabeth Ann to Charlestown. The surnames of these pioneering families were Murray, Murphy, Harrigan, Connors, O’Leary, Loring, and Carroll and all "were good mechanics and came to America with the determination to make the best possible use of the advantage of a free country" (Anon 1886: 1). The text hints that the reason for the inclusion of the article in the newspaper was in response to a recent address on the early history of Lowell by C. C. Chase, who had referred to the first Irish settlers having lived in huts. We can surmise that the lady subscriber had seen this as a possible slight to the city's Irish population and their ancestors, and a significant element of the article highlights the quality of the folk who arrived in 1819 and in later years, the hard work they undertook, and how their descendants had flourished. One has to assume that much of this narrative was based on family folklore and community knowledge, but the lady subscriber certainly demonstrated good knowledge of the social conditions within Ireland in 1819 when she noted that the principal reason for the emigration of the pioneering group "was the disturbed state of the old country at that time. There was much local bitterness caused by the misguided zeal of rival secret societies - notably the Orangemen and the Ribbonmen; and even those who would not identify themselves with either faction were not safe from persecution. They were looked upon with distrust and were made the subjects of revengeful assaults upon their property or persons" (Anon 1886: 1). The Ribbonmen were an early nineteenth-century Catholic movement in north Leinster, north Connacht, and Ulster who acted as a bulwark against the Orange Order, with whom they clashed frequently, while the latter was born out of Protestant sectarianism in the 1790s and was blamed for concerted attacks, particularly in County Armagh, which forced an estimated 7,000 Catholics to leave their homes and move to north Connacht. Recent research by Cunliffe (2017: 4) has focused on the site of a refugee camp in east Galway for some of these Ultachs (derived from Ultach, an Ulster person), as they became known. At the heart of much of these religious sectarian tensions, however, were economic difficulties.

Leaving aside the settlers of 1819 , the development of a significant Irish presence into the Chelmsford area crystallized around the work necessitated by the Boston 
Fig. 1 Map showing the location of Lowell, Massachusetts, and key places mentioned in the text (Prepared by Libby Mulqueeny)

Associates. John Green, appointed as the doctor for the works and arriving on April 23, 1822, related in his autobiography that Kirk Boott, Agent of the newly formed Merrimack Manufacturing Company, took up residence in the settlement on April 15, 1822. Boott had responsibility for the execution of the Associates' plans on the ground and Green proceeded to write that it was about this time that Charles Blaney "with a gang of two hundred Irish laborers, had begun on a large contract for digging the canals, and for the foundation of Mill No.1" (Green 1887: 233). Given his surname, it can be assumed that Blaney was Irish, but he was not the only Irish labor boss with crew in Lowell. Hugh Cummiskey (1789-1871), based in Boston, supplied 30 Irish workers who walked to Lowell on April 5, 1822, and commenced work the next day. Someone who clearly had organizational talent, Hugh had worked as a construction foreman at the Charlestown Docks at the terminus of the Middlesex Canal and, for a time, also owned his own brewery in Charlestown. He and his elder brother James (1780-1833) would develop a reputation for undertaking major land-moving contracts, cutting down hills, and filling low spots, such as at the Charlestown Navy Yard in the mid to late 1820s (Seasholes 2003: 90), but he was also to become a leader of the Irish in Lowell, particularly once he moved there permanently in 1828. From his naturalization papers from 1821 we know that Hugh came from Crossan, a townland of 367 ac [148 ha] in the Parish of Kilskeery near the village of Dromore in County Tyrone in the northern province of Ulster. He had moved to Boston in 1817 when he was 28 years old and was joined by James in the following year.

Evidently Hugh and James had left their farmstead in Tyrone to further their ambitions abroad. In the period from 1800 through to the Great Famine's commencement in 1845 some one million Irish emigrated to north America, with mass migration established by 1825 and Catholics, such as the Cummiskeys, replacing Presbyterians as the major component in the emigrant flow (Fitzgerald and Lambkin 2008: 161-163). The years 1817 to 1818, when Hugh and James both left Crossan for Boston, hint at the pressures which fuelled this migration. In the aftermath of the Napoleonic Wars (180315) and the Anglo-American War (1812-15) the United Kingdom of Great Britain and Ireland had entered an economic recession, coinciding with the 1816 "Year without Summer." As a result of the eruption of the Mount Tambora volcano in modern Indonesia in 1815, the harvests failed and famine was reported in Ireland, with an associated outbreak of typhoid, and an estimated 100,000 deaths. Ongoing religious sectarian tensions and outrages also had to be contended with, alluded to in the aforementioned newspaper article of 1886 (Anon 1886: 1). The pressure to migrate was therefore strong for those with the ability to make the move-such as the new arrivals to East Chelmsford in 1819 - to a new nation-state that was beginning to develop its infrastructure: "Migrants in the decades before 1845 were increasingly conscious that expanding America could find places for those with little more to offer than a strong back, impressive stamina and sheer determination" (Fitzgerald and Lambkin 2008: 159). This in turn led to "chain migration," with the Cummiskeys bringing relatives and neighbors from Dromore across to Massachusetts to work with them on their projects. 


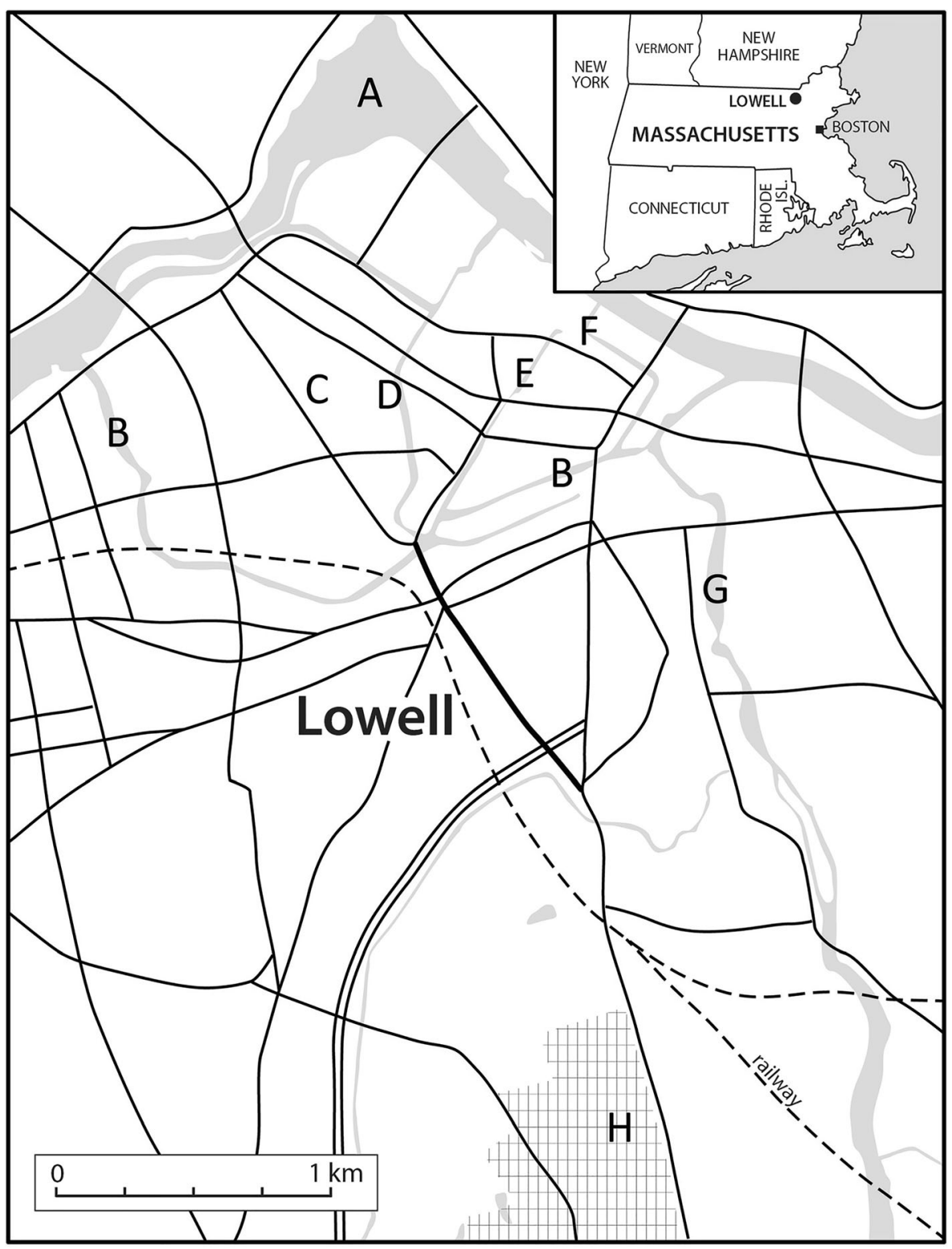

\section{LOWELL,}

MASSACHUSETTS
A: Merrimack River

B: Pawtucket Canal

C: North Commons

D: St Patrick's Church in the Acre

E: Merrimack Canal

F: Merrimack Mills

G: Concord River

H: St Patrick's Cemetery 
A summary of Hugh Cummiskey's life in Boston and Lowell is included by local historian Michael McCaughey (1992: 96-99) in his book Come Listen a While. The source of McCaughey's information on Hugh's story in Lowell would seem to have been Edward Harley, who worked at that time in the Lowell City Library, and the two men had been in communication with each other through Fr. Joseph McCann. In a letter dated March 12, 1991 McCaughey recounted to Fr. McCann how he had gone to Crossan and spoken to the two oldest residents, aged 94 and 96 years, who told him that the last Cummiskey to live in Crossan was John (Hugh's nephew), who had died around 1880, and that all the other members of his family had emigrated to America in the early 1800s. Oral history recently obtained from local historian Aidan O'Neill further elaborates on the significance of the Cummiskey homestead in Crossan to this process of early nineteenth-century emigration from Tyrone. Any local men who wished to emigrate and work with Hugh Cummiskey in Boston or Lowell had first to visit the family cottage at Crossan and be checked for their suitability by members of the Cummiskey family (Donnelly and Allmond 2011: 4). Perhaps assistance was given with their fare and the newly emigrated laborer was then to pay back that financial assistance through their work with Hugh in Massachusetts, but it was in this way that so many men from Dromore and Trillick-with surnames such as McCosker, McLaughlin, McSorley, and McQuaid - made their way to Lowell. The settlers from this Tyrone connection were an important element in the early Irish community in Lowell, but they were not alone and Mitchell (1988) has highlighted how more Irish workers made the trip to Lowell as the 1820s progressed, basing themselves in a squatter's camp — the Paddy Camp — which developed into a settlement known as The Acre. This was located close to where the band of Irish migrants in 1819 had set up their camp, and was a tough working community with scant amenities, as can be judged from contemporary accounts and memories, set on the edge of Lowell's developing urban landscape. By 1831 it had an estimated population of 500 Irish settlers and a wooden Roman Catholic church had been constructed in the center of the community; 30 years later, the Irish population had grown to represent half of Lowell's population of 36,827 (Marston 1991: 216; Mitchell 1988: 157).

\section{St. Patrick's Cemetery}

Given the rising Irish Catholic population, Kirk Boott facilitated Boston's Roman Catholic bishop, Benedict Fenwick, in the latter's efforts to administer to this community. In 1827 the bishop sent Fr. John Mahoney, a missionary priest from County Kerry, to administer in Lowell but he also had to share his time with St. Mary's Parish in Salem. Boott, however, encouraged Bishop Fenwick to provide Lowell with its own priest and he granted an 8,410- $\mathrm{ft}^{2}\left[781 \mathrm{~m}^{2}\right]$ lot near the Western Canal for the establishment of a church, to be named St. Patrick's, which was dedicated on July 3, 1831 (Mitchell 1988: 34-39).

Undoubtedly there were deaths within the Irish population during the 1820 s. While no supporting evidence has been identified, it is possible that some were buried within the pre-existing cemeteries in the Chelmsford area, such as the Old Burying Ground at Dracut or the School Street Cemetery, opened in 1810. We do know, however, that 
some of Lowell's Catholic dead were brought to the St. Augustine's Cemetery in South Boston, opened in 1818, and to Bunker Hill Roman Catholic Cemetery in Charlestown, opened around 1830, so they could be interred in consecrated ground. Local history reports that this work was undertaken by an Irishman, Denis Crowley (McKean 2016: 22-23). Bishop Fenwick's correspondence, however, contains an entry for April 10, 1832 which confirms the establishment of a Catholic burial ground in Lowell in that year:

A day similar to yesterday. Rev'd Mr. Mahoney arrives from Lowell \& states that a burying ground has been purchased close to town on the road to Bilricky [Billerica, MA] \& that it is in every respect a desirable spot for the internment of the dead. He states farther that Kirk Boott Esq'r has given another Lot fronting the Cath church for their better accommodation (McKean 2016: 23).

Evidently, Boott was continuing to facilitate the development of the Roman Catholic Church's presence in Lowell and his award of another lot of land close to the church may have been provided for a new parochial house. The new Catholic burial ground would later come to be known as St. Patrick's Cemetery (to distinguish it from other Catholic burial grounds in Lowell established later in the nineteenth century) and its acquisition would have been of great relief to the bishop, who was coming under pressure from the citizens of Boston, concerned about the number of individuals from Lowell who were being interred in the burial grounds at both St. Augustine's and Bunker Hill. Boston's authorities had indicated that such burials might be stopped, and there are records of the dead having to wait for burial while disputes were resolved (McKean 1997: 2).

We have no way of knowing how many bodies were brought to Boston for burial during the 1820s. George O'Dwyer (1920: 60) reported the names and dates of death for 22 individuals from Lowell and Chelmsford who were buried in St. Augustine's Cemetery in the years 1823 to 1847 . Evidently not a comprehensive list, most of the burials (18 out of 22) had taken place in the years before 1832 and the opening of St. Patrick's Cemetery in Lowell, which chimes with the ending of Boston burials at this time. Some burial evidently continued to take place in St. Augustine's, however, given that four burials on the list date to the 1840s (one in 1844, one in 1845, and two in 1847). These may represent individuals who wished to be interred with other family members who had already been buried in the cemetery prior to the opening of St. Patrick's Cemetery, given that one individual (Catherine Gorman 1847) died aged 72 years, and another (Rose McDermott 1845) died aged 86 years. The erection of St. Patrick's Church and the establishment of the Catholic cemetery also made a clear statement in the early 1830 s that the Irish were not a temporary presence in Lowell; they were intent on staying (McKean 1997: 2).

St. Patrick's Cemetery is still in use today; it is the second oldest Roman Catholic cemetery in the Archdiocese of Boston and contains the remains of an estimated 130,000 people (McKean 1997: 7). Now organized into a series of yards, it would seem that the early burial ground had little form or pattern:

In the early days there was no charge of any kind connected with burial in the Cemetery. When death came to any member of Lowell's little Catholic 
community the relatives of the decease might secure a burial place for the asking. Friends of the family dug the grave and bore the body to its last resting place. The cemetery then was nothing more than a field set apart and dedicated to burial purposes (Anon 1933: 1).

The situation at St. Patrick's contrasts with that at the Lowell Cemetery, founded nine years later in 1841, and which followed the fashionable trend of being a garden cemetery. The Mount Auburn Cemetery had been established in the Boston area in 1831 and was the first garden cemetery in the English-speaking world. It soon became a model for other burial grounds such as the example in Lowell, conceived not only as a place of burial but intended to be used for walking and peaceful meditation while enjoying the beauty of nature. Indeed, at its dedication on June 20, 1841, Rev. Amos Blanchard stated that it would be a "place to tranquilize and elevate the soul," in contrast to the "abodes of desolation" that he considered to characterize Lowell's other burying grounds (Goodwin 1992: 1-2).

\section{The Early Memorials in St. Patrick's Cemetery}

St. Patrick's Cemetery contains a rich array of nineteenth-century granite, marble, and slate memorials. Since 1996, local volunteers have cleaned and recorded over 700 memorials in the earliest sections of the cemetery-Yards One, Two, and Three-while field recording was also undertaken by the current authors in 2011 and 2015 in Yard One. As a result of this latter work a corpus of 139 of the earliest memorials are available for study. Previous studies of grave memorials have indicated their value for investigating issues related to religious and ethnic identity, with "powerfully overt" differences in commemoration practices evident between migrant and host populations (Mytum 2004: 145). The current study clearly demonstrates the contribution that headstones can make in the context of the Irish diaspora. Although the first generation of Irish settlers left almost no primary source material, the examination of the iconography and epitaphs included on the memorials Yard One can contribute to our understanding of the identity of these Irish pioneers and how they expressed their religion and ethnicity in their new homeland.

\section{Stone Carvers}

The first generation of Irish buried in St. Patrick's followed the example of their Yankee contemporaries and used black slate stone for their memorials. Historical sources indicate that slate had been quarried locally since colonial times (see Dethlefsen and Deetz 1966: 503), at Pin Hill quarry in Harvard, Massachusetts, as well as in southern New Hampshire, and was readily available and moderately priced (Day 2005: 9). Indeed, around 1842 the firm of Winslow, Folsom, and Company of Lowell became briefly involved in slate mining at the Pin Hill quarry when they attempted rather unsuccessfully to introduce blasting as a more efficient method for acquiring the necessary stone (Nourse 1894: 450-451). The slate memorials represent the initial decades of the burial ground's use from its opening in 1832 up to 1854 (99.3\%; 138/ $139)$, with only one definite later example uncovered to date. This comprised a 
poignant headstone erected in 1860 in memory of two infants-Thomas Moore who died on August 27, aged eight months and seven days, and Ellen Moore who passed away on November 23, aged five months and six days. This, however, was in the era when slate was passing out of use for headstones. Nourse (1894: 451) noted that Deacon Isaac Stone extracted slate from the Pin Hill slate quarries until 1863, stating that: "The fashion in mortuary monuments favoring marbles and granite, there has been little use made of the Pin Hill slate since his day."

A number of local stone carvers, including Benjamin Day and Theodore Warren, are known to have established workshops in the Lowell area as evidenced by their inscription on the base of some of the memorials (McKean 1997: 9). The best known of these carvers is Benjamin Day who, the historical records suggest, began carving slate memorials as early as 1807 in Salem but who then became based in Lowell at some stage between 1824 and 1830. By 1832 he was listed in the Lowell Street Directory as a stone cutter at Lowell Street, boarding at Whipples, and he appears to have remained in Lowell until his death in 1855 (Day 2005: 2, 4, 6, 17). The earliest stone in St. Patrick's with details of the stone carver inscribed on it dates to 1832, just after the cemetery was opened, and is in memory of John Bork and was the work of Day. The stone is typical of what one might find in the neighboring Yankee cemetery with its Classical willow and urn motifs and verse (see below and Fig. 2).

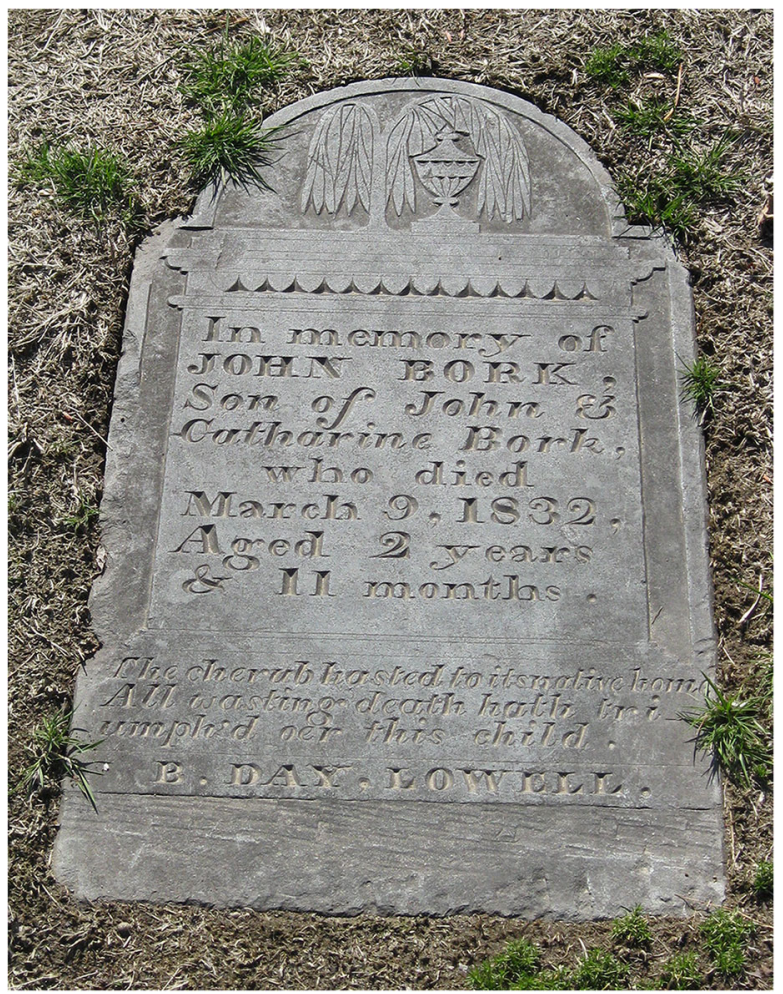

Fig. 2 Grave memorial erected for two-year-old John Bork (Bourke) who died in 1832, carved by Benjamin Day, and which closely follows the traditional Yankee formula for memorials (Photograph Eileen Murphy) 
The next two examples of headstones with the stone carver named on them are also the work of Benjamin Day and date to the years 1833 and 1838. Significantly, by 1833 - a very early date in the history of the new cemetery - Day had started to include the IHS monogram within a Latin cross as an additional motif on his memorials, alongside the willow and urn motifs. The IHS monogram (or Jesus monogram) had become a symbol of Counter-Reformation Catholicism. "The symbol originated in a Medieval cult of the Holy Name of Jesus as a Latinized version of the Greek abbreviation 'I H (E O Y) E' for 'J E (S O U) S'. The letters have also been interpreted (with conscious intention of enriching the meaning) as Iesus Hominum Salvator for 'Jesus Savior of Mankind', and In Hac Salus, 'In This (Cross) Salvation"' (Bryce and Roberts 1993: 369). The headstone, erected in memory of Cornelius Hartley who had died in 1833 aged 41 years, is the earliest known example of the IHS monogram on a gravestone in St. Patrick's Cemetery and suggests that the person responsible for the marriage of Roman Catholic and Classical motifs might have been Day, although it should be noted that slate headstones with these motifs are found elsewhere in Massachusetts. At St. Augustine's Cemetery in South Boston, for example, the headstone of Hugh Cummiskey's brother James (1780-1833) includes an IHS monogram within a Latin cross flanked on either side by willow trees. The next of Day's known memorials recorded the death of Francis McLaughlin from Dromore in County Tyrone, a little over four years later in 1838, and the slate headstone is decorated with a willow, urn, and an IHS monogram within a Latin cross.

There is then a gap of nine years between the last known stone by Benjamin Day (1838) and the next named stone, dated to 1847 and erected in memory of Elizabeth Newman from King's County (now County Laois) who died at the age of 19 years. The carver this time is recorded as T. Warren, presumably the aforementioned Theodore Warren, and is decorated with a willow and an IHS monogram within a Latin cross. It is notable that Warren opted to use the combined Catholic and Classical symbolism favored by Day, indicating that the concept was enjoying usage among other stone carvers in the Lowell area. The name of the stone carver, J. Hurley, associated with a later headstone, dating to 1858 and erected in memory of Patrick Keyes and his wife, is perhaps significant. Hurley is an identifiable Irish surname and may represent an example of an individual with Irish ancestry who had commenced work in the stone carving business. If so, it is also of interest to note that he opted not to work in slate, but in marble, and that he used purely Roman Catholic symbolism - a lamb and a cross.

\section{Form and Iconography}

The slate headstones in Yard One are of two main forms - a round top with stepped shoulders, and a flat top. Analysis of a subset of the memorials with associated photographs indicates that the rounded top and stepped shoulder form greatly predominates (87.7\%; 93/106 of complete memorials). As discussed above, it is important to remember that these craftworkers were Yankees, who would have followed styles and designs mandated by tradition. Often the upper part of the headstone, which contained the ornamentation, would have been carved in advance and the purchaser would tell the carver the names and dates to be added, while most memorials of this period in New 
England had a willow and urn design etched into them. The weeping willow was a symbol representing mourning and the urn was reminiscent of the Classical World symbol of cremation ashes. These motifs became common in New England during the late eighteenth and early nineteenth century and became universally used within a short time. They were the first signs of a changing attitude toward nature and death that would become fully manifest in the later garden cemeteries. They are also considered as evidence of a growing spirit of romanticism, as well as an appetite for neoclassicism, within the new American Republic (Linden 1980: 149-150).

As mentioned above, some of the earliest memorials in St. Patrick's are identical to those found in contemporary Yankee cemeteries and follow a similar formula. The oldest memorial, carved by Benjamin Day and dating to 1832, for example, commemorates two-year-old John Bork (Bourke) and its layout is practically identical to Yankee memorials in the Old English Cemetery, also carved by Day (Fig. 2).

The carvers who made the grave memorials may not have thought in great depth about the philosophical aspects of the symbols and messages they placed upon their products but the headstones evidently required community acceptance; the iconography had to resonate with the values, beliefs, and tastes of the host society (Linden 1980: 149). As noted above, within the first years of burial in Yard One an interesting enhancement was added to the slate memorials with the addition of a Latin Cross and the IHS monogram alongside the Classical motifs of the willow and/or urn. Contemporary Yankee slate stones do not have these emblems, in keeping with a more formal Puritan tradition, and they avoided any connection to what might be viewed as explicitly Roman Catholic symbols.

When we examine the nature of the symbols at the top of the St. Patrick's memorials some 19 variations are apparent. A total of $14.0 \%$ (15/107 with complete decoration visible) of the memorials display designs that are represented by only one or two instances and are therefore uncommon variants (Table 1). The proportions of the remaining designs are summarized in Fig. 3. Memorials with a weeping willow and a Latin cross inscribed with the IHS motif greatly predominate $(51.4 \% ; 55 / 107)$, with the combinations of a weeping willow, IHS-inscribed Latin cross and shamrocks $(15.0 \% ; 16 / 107)$ or a weeping willow with an urn $(6.5 \% ; 7 / 107)$ occurring in next greatest proportions. It therefore appears to be the case that most of the early Irish headstones simply replaced the Classical urn from the Yankee package of motifs with the IHS-inscribed Latin cross as a symbol of their Catholicism. This design does not appear to be associated solely with the earliest burials in the cemetery, as one might expect, but rather spans the entire period of this study, with the earliest example dating to 1833 and the latest to 1853 . Aside from these enhancements, the headstones otherwise appear identical to their Yankee counterparts in other cemeteries in the region. By having such symbols incorporated into their headstone design, however, the first generation of Irish in Lowell were-intentionally or not-setting themselves apart from their Yankee contemporaries.

\section{Shamrocks}

The IHS monogram was then a popular Catholic motif and its appearance on the headstones in Yard One should not be too surprising if the Irish in Lowell were keen to demonstrate their connection to Catholicism. Another motif appears on 21 of the 
Table 1 Details of all variations of decoration apparent on the slate memorials from St. Patrick's Cemetery $(n=107)$

\begin{tabular}{lll}
\hline Decoration & N & $\%$ \\
\hline Weeping willow with Latin cross \& IHS & 55 & 51.4 \\
Weeping willow with plain Latin cross & 5 & 4.7 \\
Weeping willow with plain Latin cross on 3 stepped base & 3 & 2.9 \\
Weeping willow with Latin cross \& IHS with urn & 3 & 2.9 \\
Weeping willow with urn & 7 & 6.4 \\
Weeping willow with 2 urns & 1 & 0.9 \\
Weeping willow with Latin cross \& IHS with shamrocks & 16 & 15 \\
Weeping willow with Latin cross \& IHS, shamrocks and urn & 3 & 2.9 \\
Weeping willow with Latin cross \& IHS with oak leaves & 2 & 1.9 \\
Weeping willow with urn with 2 Latin crosses \& IHS & 1 & 0.9 \\
Weeping willow with Latin cross \& IHS with 2 urns & 1 & 0.9 \\
2 weeping willows with Latin cross \& IHS & 1 & 0.9 \\
Latin cross \& IHS with shamrock and urn & 1 & 0.9 \\
Large Latin cross \& IHS & 2 & 1.9 \\
Large Latin cross \& IHS with shamrock & 1 & 0.9 \\
Large IHS with Latin cross & 1 & 0.9 \\
IHS inscribed Latin cross on pedestal in domed temple with oak leaves & 1 & 0.9 \\
Central sun \& IHS with moons with urns & 1 & 0.9 \\
No decoration & 2 & 1.9 \\
Total & $\mathbf{1 0 7}$ & \\
\hline
\end{tabular}

known memorials in the yard, however, and was a clear statement of the ethnicity of the dead within the cemetery - the use of the shamrock, the trefoil plant related to clover that is a recognized symbol of Ireland (Fig. 4). No contemporary historical sources make mention of the tale that St. Patrick, Ireland's patron saint, made use of the shamrock as a means of demonstrating the Holy Trinity to the pagan Irish he preached amongst in the fifth century CE but it is a legend that had become well-known, presumably from Irish folklore. The interconnection between green shamrocks as a symbol of St. Patrick and of Ireland had become established by the early modern period. It is certainly the case that shamrocks were worn in people's hats on St Patrick's Day (March 17-the ascribed date of the Saint's death), a practice in vogue from at least the second half of the seventeenth century (Nelson 1991: 37), as too was the tradition of holding gatherings in honor of the Saint, with much alcohol consumed by the populace. The humble shamrock had become a device to denote Ireland by the eighteenth century, used by Catholics and Protestants alike; it had increasingly appeared on flags, glass goblets, seals, medals, and military belt plates, and was worn by King George IV during his ceremonial entry into Dublin during his visit in August 1821 (Nelson 1991: 71-75). It was evidently also the case that this Irish symbol had made its way across the Atlantic to the United States by the early nineteenth century, as demonstrated by its appearance among the symbols depicted upon the slate headstones in St. Patrick's Cemetery. 


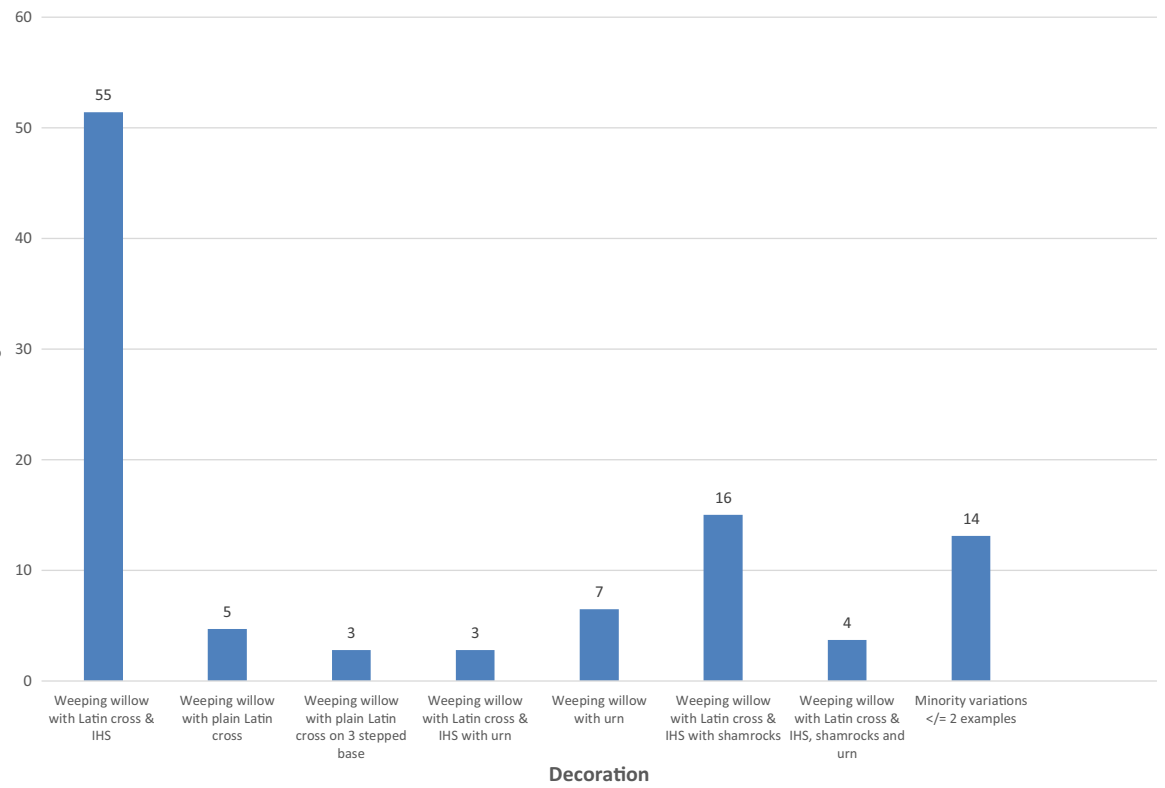

Fig. 3 Graph summarizing the main types of decoration evident on the slate memorials from St. Patrick's Cemetery $(n=107)$

The use of shamrocks on these early memorials is interesting because it suggests that at least some of the early immigrants wanted to display evidence of both their Irish and their Catholic identities (Table 2). As was the case for the predominant package of motifs discussed above, the memorials are not restricted to a narrow time period but rather span the years 1832 to 1851 . The shamrock motif does not appear to have been the preserve of any particular age group and was included on memorials erected initially for predominantly adults $(71.4 \% ; 15 / 21)$ but also children $(28.6 \% ; 6 / 21)$, with women $(n=8)$ and men $(n=7)$, as well as girls $(n=4)$ and boys $(n=2)$, aged less than 18 years, all included. The youngest person to have had a memorial with a shamrock was three-month-old John Campbell (died 1833), while the oldest was 64-year-old Bridget Rowney (died 1834). Some thirteen of the memorials with shamrocks contained details of county and some ten counties from across Ireland were represented. It is interesting that three of the memorials were of individuals from County LeitrimRosanna Garty (died 1844), Ann Oroarke (died 1846), and Michael Keegan (died 1847) — with the latter two both originating from the Parish of Cloon(e). Similarly, both Charles Shannon (died 1844) and Susan McCort (died 1851) derived from the Parish of Dromore in County Tyrone. It is possible that these groups of individuals were each in some way connected to others from their home parish, through family or friendships. Perhaps personal relationships influenced the inclusion of shamrocks on the memorials of their loved ones.

Four arrangements of motifs were evident, and shamrocks were found with a weeping willow and an IHS-inscribed Latin cross $(76.2 \%$; 16/21); a weeping willow, IHS-inscribed Latin cross and an urn $(19.0 \% ; 3 / 21)$; an IHS-inscribed Latin cross and an urn $(1 / 21)$, and a notably large IHS-inscribed Latin cross $(4.8 \% ; 1 / 21)$. It is therefore 
clear that the variant largely involved the addition of shamrocks to the most common pattern of motifs, the weeping willow with an IHS-inscribed Latin cross.

The style of the shamrocks also displayed variation, with most memorials depicting a shamrock plant on either side of the central motif $(81.0 \% ; 17 / 21)$, and only four memorials having shamrock present on one side only, counterbalanced by an opposing urn. It seems significant that three of the earliest memorials (Barry died 1832, Campbell died 1833 and Rowney died 1834) have a single stalk presentation of the plant and this perhaps suggests that the memorial carvers lacked the confidence to portray the plant in the more realistic manner apparent in later designs. It should be noted, however, that while the Barry and Rowney memorials both depict a single leaf, the shamrock on the Campbell headstone displays three leaves. The first entry on the Campbell headstone dates to 1833 for three-month-old John, with this mother, Mary Ann, added in 1840 . While it is possible the memorial was not erected until around 1840, the differing writing styles for the two entries and their chronological order would tend to suggest

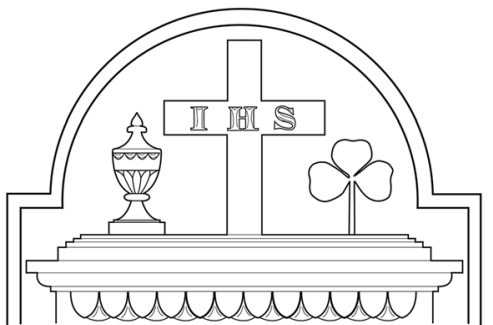

MARY BARRY d1832

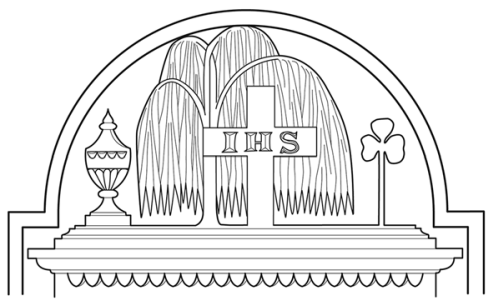

3



5
DANIEL CARLIN d1836

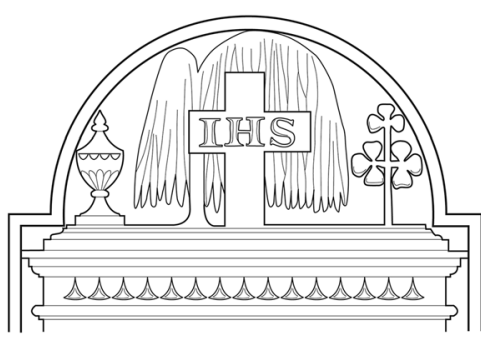

2 JOHN CAMPBELL d 1833 MARY ANNE CAMPBELL d1840

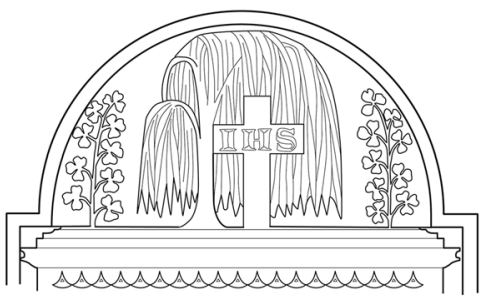

$4 \quad$ MARGARET DOYLE d1835

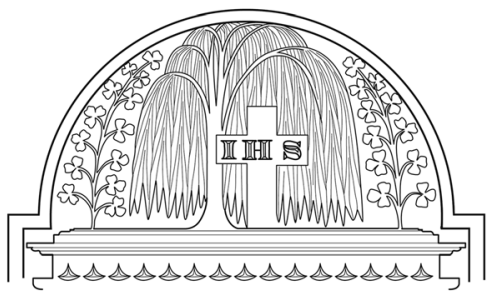

6 ELLEN OCONNOR (O'CONNOR) d1836

Fig. 4 Drawings of the arrangements of the decorative motifs included at the tops of the 21 memorials with shamrocks from St. Patrick's Cemetery (Drawn by Libby Mulqueeny) (also see Table 2) 


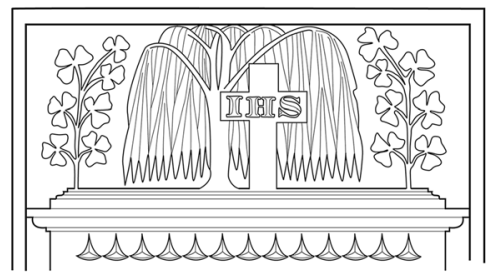

7

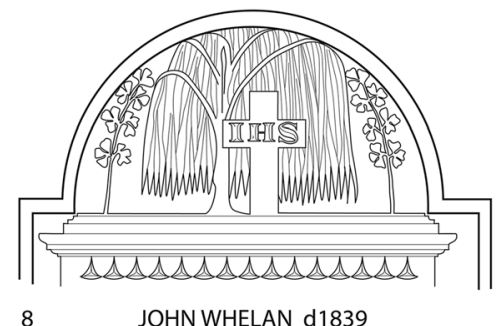

$8 \quad$ JOHN WHELAN d1839

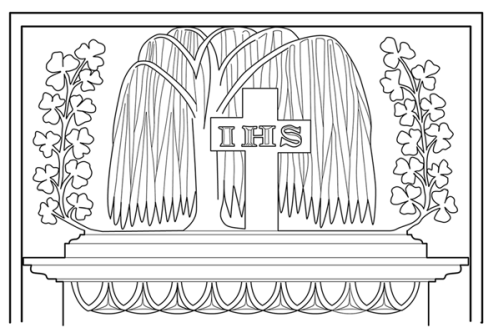

9

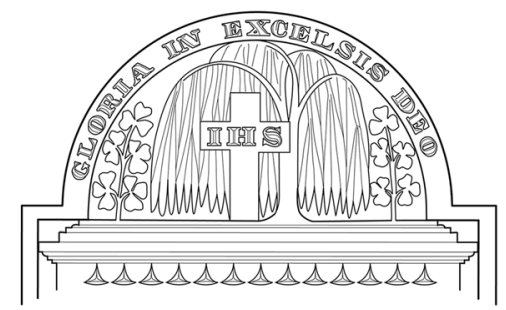

11 PATRICK \& THOMASTIERNAN d1840

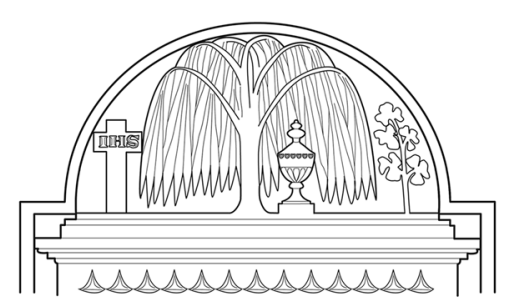

10 THOMAS KELLY d1840

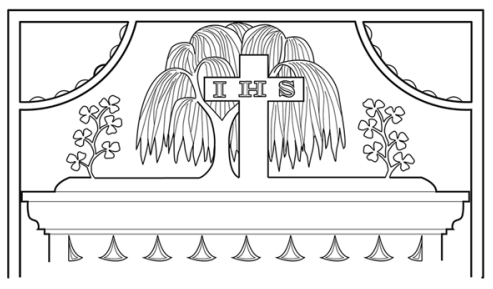

MICHAEL ENRIGHT d1841

Fig. 4 (continued)

that it was erected initially for John with the entry for his mother added at a subsequent date.

It is interesting that the earliest manifestation of a shamrock, on the 1832 memorial for 12-year-old Miss Mary Barry, omitted the ubiquitous willow tree, favoring a central cross flanked on either side by an urn and single shamrock. Perhaps her parents, who erected the memorial, did not view the willow tree as an appropriate inclusion on the memorial although it is interesting that an urn was present. A later memorial, dated to 1840 and erected for Thomas Kelly, also displayed a single stalk of shamrock, in this case with five leaves. The arrangement of motifs in this instance is unusual since a central willow and urn dominate, with a small IHS-inscribed cross positioned far to the right side counterbalanced by the shamrock to the left. Perhaps the carver was experimenting with the configuration of motifs or cost may have been a factor and those who purchased the memorial could not afford a bespoke design, having to make do with adding the Irish Catholic symbols to a near-complete, ready-made Yankee memorial. Indeed, Henry Nourse (1894: 450) observed that memorial carvers would 


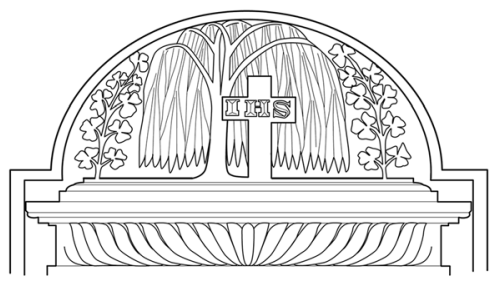

13

ANNE MCAVOY d1842

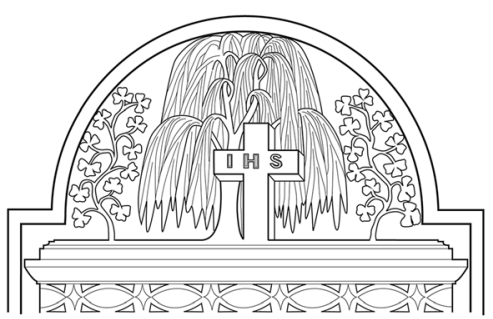

15

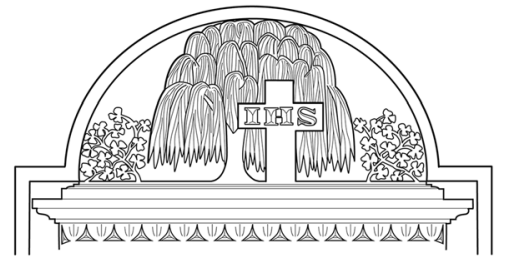

14 BRIDGET MURTAGH d1843

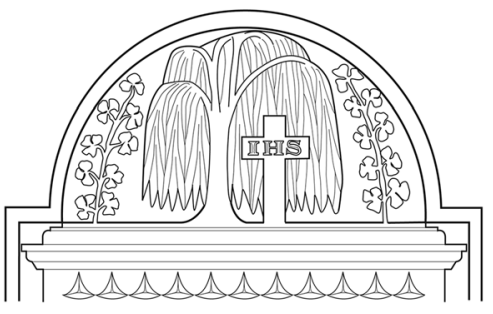

16 CHARLES SHANNON d1844

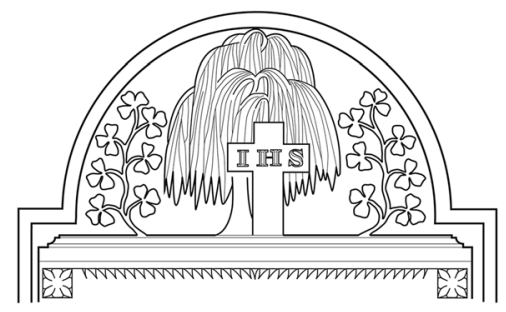

18 ANN OROARKE (O'ROURKE) d1846

Fig. 4 (continued)

have had a collection of ready-made memorials on display to attract prospective customers.

Substantial variation in terms of the number of leaves present is evident in the memorials displaying bilateral shamrock stalks, with examples of five $(n=1)$, six $(n=$ $3)$, seven $(n=3)$, nine $(n=2), 11(n=2), 12(n=2)$ and $14(n=1)$ leaves present. In addition, a further three memorials display bilateral shamrock arrangements in which the numbers of leaves are asymmetrical. The memorial for Ellen OC'nnor [O'Connor] (died 1836) displayed 13 leaves on the right and 11 on the left, that of Charles Shannon (died 1844) had 11 on the right and nine on the left, while the headstone of Mary McDermott (uncertain date) contained 30 shamrock leaves on the right and only 22 on the corresponding left side. It seems probable that the design on the right side of these memorials would have been created initially by a right-handed carver. In the case of the OC ${ }^{\circ}$ nnor [O'Connor] memorial the central willow was notably large and the positioning of the IHS-inscribed cross to the left of the tree trunk meant there was 


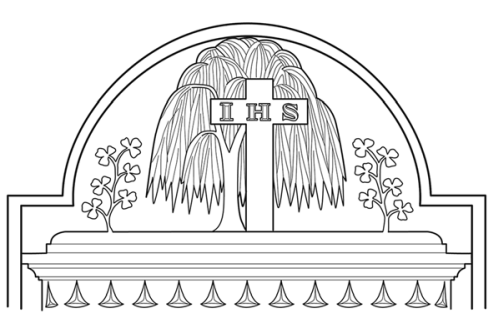

19

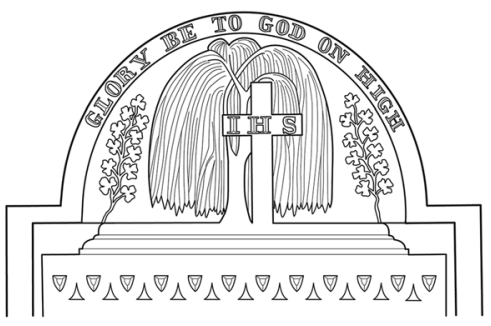

20

SUSAN MCCORT d1851

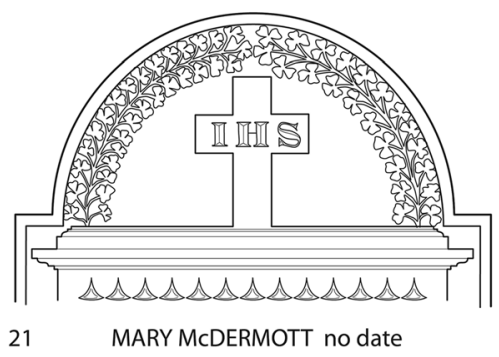

Fig. 4 (continued)

genuinely less space on the left side for the shamrock design. For the Shannon and McDermott memorials the asymmetry does not appear to have been due to a lack of space and was executed perhaps unconsciously by the carver. The skill of the carver in all three cases, however, means the asymmetry is only noticeable when effort is taken to count the leaves.

The form of the shamrock depictions also show variation. Most cases with more than one leaf $(72.2 \%$; 13/18) have a single stalk from which each leaf emanates directly on a single stem, and only four $(22.2 \% ; 4 / 18)$ examples display additional stems with further leaves detached from the central stalk. A further, highly unrealistic, example depicted shamrocks with no stems attached directly to a central stalk (Whelan died 1839). The three earliest examples (Barry died 1832, Campbell died 1833, Rowney died 1834) were rigid in form with the stalk set at right angles to the base of the upper decorative area of the memorial. Most later cases $(66.7 \%$; 12/18) displayed medial curvature of the stalk that mirrored the curvature of the rounded top of the headstone; these forms were somewhat animated but still highly stylized. More realistic portrayals of the plant $(33.3 \% ; 6 / 18)$, which capture its somewhat "springy," lively appearance, were also depicted, however, with the most naturalistic carvings evident in the memorial of Bridget Murtagh (died 1843). It is interesting that the shape of the leaves, with the indentation at its tip, are realistically depicted in all but one of the carvings (Campbell died 1833). The shape of the leaves in the shamrocks on John Whelan's (died 1839) memorial are the least accurate and, rather than depicting a tripartite leaf, the carving includes a set of three small and practically individual leaves. It would seem to be the case, however, that in the main the carvers had been shown real shamrocks or else, perhaps more probably, drawings of shamrocks. 
Table 2 Details of the 21 slate memorials containing a shamrock motif from St. Patrick's Cemetery (numbers refer to Fig. 4)

\begin{tabular}{|c|c|c|}
\hline Name & Date & Epitaph \\
\hline 1. Mary Barry & 1832 & $\begin{array}{l}\text { In / Memory of / MISS MARY, / Daughter of / James \& Mary Barry / } \\
\text { Who died / June 29, 1832, / AEt. } 12 .\end{array}$ \\
\hline 2. John Campbell & 1833 & JOHN, Son of / James \& Mary Ann / Campbell, Obt. / Aug. 5, 1833, / AEt. 3 months. / \\
\hline Mary Ann Campbell & 1840 & MARY ANN/CAMPBELL, died / March 11, 1840, / AEt. 29./ May her soul rest in peace. \\
\hline 3. Bridget Rowney & 1834 & IN / Memory of / BRIDGET ROWNEY, / Who died / July 22, 1834, / AEt. 64. \\
\hline 4. Margaret Doyle & 1835 & $\begin{array}{l}\text { SACRED / To the memory of / MARGARET DOYLE, / who departed this life / } \\
\text { Dec. 28, 1835. / AEt. 22. / Also in memory of / JOHN, Son of / Michael Harragon, } \\
\text { / who died Nov. 27, 1835./ AEt. } 2 \text { yrs. / Requiescant in pace, Amen. / Erected by } \\
\text { Daniel McCarthy / Of Timoleague in the / County of Cork. Ireland. }\end{array}$ \\
\hline 5. Daniel Carlin & 1836 & $\begin{array}{l}\text { In memory of / DANIEL CARLIN. / A native of the County / of Armagh, Ireland. / } \\
\text { Who died / Apr. 15, 1836. / AEt. 51. / Erected by his daughter / MARY CARLIN. }\end{array}$ \\
\hline 6. Ellen OConnor & 1836 & $\begin{array}{l}\text { Gloria in excelsis Deo. / SACRED / To the memory of / ELLEN OCONNOR, / Daughter of } \\
\text { Patrick \& / Johannna Fitzgerald, and / Wife of Daniel OSullivan. / Natives C }{ }^{\circ} \text {. Kerry } \\
\text { Ireland, / Who departed this life / March 1, 1836, / AEt. } 17 \text { years. / Requiescant in pace. } \\
\text { Amen. }\end{array}$ \\
\hline 7. Margaret Kennedy & 1837 & $\begin{array}{l}\text { ERECTED BY / PATRICK COMMONS, / To the memory of / his daughter / MARGARET, wife of / } \\
\text { THOMAS KENNEDY, / Died Jan. 13, 1837, / Aet. 19./ ALSO ELLEN, / Their daughter / Died } \\
\text { March 1837, / AEt. } 12 \text { mon's. / May they rest in peace. / Amen. }\end{array}$ \\
\hline 8. John Whelan & 1839 & $\begin{array}{l}\text { IN / Memory of / JOHN WHELAN, / Of Waterford Ireland, / Who died in Lowell / } \\
\text { July 6, 1839. / AEt. 25. / May his soul rest in peace. }\end{array}$ \\
\hline 9. Jane Daly & 1840 & $\begin{array}{l}\text { In Memory of / JANE, / Daughter of Terence / \& Bridget DALY, died / Feb. 9. 1840, / } \\
\text { Aged } 3 \text { years / \& } 7 \text { mons. }\end{array}$ \\
\hline 10. Thomas Kelly & 1840 & $\begin{array}{l}\text { In memory of / THOMAS KELLY, / A native of Ireland / County Mayo, half / Barony of } \\
\text { Iris, and / Parish of Killcommon, / Who died / Feb. 10, 1840. / AEt. 52. / May his soul } \\
\text { rest in peace. / Amen. }\end{array}$ \\
\hline $\begin{array}{l}\text { 11. Patrick and } \\
\text { Thomas Tieman }\end{array}$ & 1840 & $\begin{array}{l}\text { GLORIA IN EXCELSIS DEO. / To the memory of / PATRICK TIERNAN / A native of } \\
\text { Longford / Ireland who died / July 1840, / AEt. } 16 \text { yrs. \& } 4 \text { mo. / He came by his death } \\
\text { / by blasting July } 4 \text {. / ALSO THOMAS. / his brother died at / Newyork, July 12, / 1840, } \\
\text { Aet. } 24 \text { y'rs / \& } 8 \text { mon's. / May their souls rest in peace }\end{array}$ \\
\hline 12. Michael Enright & 1841 & $\begin{array}{l}\text { MICHAEL F. ENRIGHT, / Died Apr. 25, 1841, / AEt. 35. / A native of the parish of Croom, } \\
\text { / Co. of Limerick, Ireland. / Their children, SUSAN, / Died Aug. 26, 1840, / AEt. } \\
2 \text { yrs. \& } 4 \text { mos. / MARGARET, / Died May 2, 1842, / AEt. } 14 \text { mos. / May they rest in } \\
\text { peace. / Erected by his wife Margaret. / Also their daughter MARY A. / Who died } \\
\text { Aug. 15, 1847, / AEt. } 15 \text { yrs. }\end{array}$ \\
\hline 13. Anne McAvoy & 1842 & $\begin{array}{l}\text { This stone was erected by / MICHAEL MCAVOY, / In memory of his wife / ANNE MC } \\
\text { AVOY, / Who died / Nov. 5, 1842, / AEt. 24. / A native of Ireland. }\end{array}$ \\
\hline 14. Bridget Murtagh & 1843 & $\begin{array}{l}\text { Gloria in excelsis Deo. / In memory of / BRIDGET MURTAGH / Who died Nov.11.1843, / } \\
\text { Aged } 53 \text { yrs. / Requescant in pace. / Erected by her son James Murtagh. }\end{array}$ \\
\hline 15. Rosanna Garty & 1844 & $\begin{array}{l}\text { Erected by / MICHAEL GARTY, / in memory of his dearly belov'd / consort ROSANNA. a } \\
\text { native / of the Co. Leitrim, Ireland. / who died May 21, 1844, / AEt. } 26 \text { yrs. / BRIDGET, } \\
\text { their daughter / died Aug. 23, 1841, AEt. } 16 \text { mos. / Requescant in pace. }\end{array}$ \\
\hline 16. Charles Shannon & 1844 & $\begin{array}{l}\text { SACRED / To the memory of / CHARLES SHANNON / A native of the Parish / of Dromore, } \\
\text { County / Tyrone, Ireland. / who departed this life / Oct. 8, 1844. / AEt. } 30 \text {. }\end{array}$ \\
\hline 17. James Mehen & 1846 & $\begin{array}{l}\text { JAMES MEHEN, / Died Jan. 9, 1846, / AEt. 26. / A native of the parish / of Colooney, Co. } \\
\text { of Sligo, / Ireland. / JOHN his son / Died Oct. 15, 1846, / AEt. } 8 \text { mos. \& } 2 \text { yrs. / May they } \\
\text { rest in peace. / Erected by his wife Ann. }\end{array}$ \\
\hline 18. Ann Oroarke & 1846 & $\begin{array}{l}\text { In memory of / ANN, / Daughter of / Farrell \& Elen / Oroarke, / Natives of Parish Cloone, / } \\
\text { Co. Leitrim, Ireland. / Who died May 17, } 1846 \text { / AEt. } 2 \text { yrs. \& } 6 \text { mos. / May she } \\
\text { rest in peace. }\end{array}$ \\
\hline 19. Michael Keegan & 1847 & $\begin{array}{l}\text { MICHAEL KEEGAN, / Died June 6, 1847, / AEt. 49. / A native of the parish of Cloon, } \\
\text { Co. of Leitrim, Ireland. / MICHAEL his son died / Feb. 8, 1841, AEt. } 3 \text { yrs. \& } 6 \text { ms. / }\end{array}$ \\
\hline
\end{tabular}


Table 2 (continued)

\begin{tabular}{lrl}
\hline Name & Date & Epitaph \\
\hline 20. Susan MoCort & $\begin{array}{r}\text { May they rest in peace. } \\
\text { 21. Mary McDemott }\end{array}$ & $\begin{array}{r}\text { In memory of / SUSAN McCORT, / Who died Feb. 6, 1851. / AEt. 32. / A native of } \\
\text { the Parish of / Dromore, Co. Tyrone, Ireland. }\end{array}$ \\
\hline
\end{tabular}

\section{Epitaphs}

In keeping with the more positive attitude towards death witnessed in the willow and urn motifs of the late eighteenth- and early nineteenth-century headstones, as discussed above, the associated epitaphs included on the slate headstones show significant levels of biographical information as well as verses associated with consolation and hope that replaced previous messages of resignation and loss (Linden 1980: 152).

As was the case with the iconography evident on the early Irish slate headstones, the inscriptions displayed traditional characteristics of the Yankee memorials but augmented to suit the religious and cultural context of the immigrants. The epitaph most frequently started with the words "In memory of ..." or a variant of this statement (56.1\%; 78/139), but a substantial proportion simply commenced with the name of the deceased $(25.9 \%$; 36/139) or the name of the person who commissioned the memorial $(15.8 \% ; 22 / 139)$. A minority of epitaphs commenced with a religious verse or prayer $(2.2 \% ; 3 / 139)$. This information was then followed by the name of the deceased and, in varying order, the date of death, their age-at-death (Aet.) and their place of origin.

\section{Place of Origin}

An examination of the epitaphs from the neighboring Old English Cemetery during the period from 1832 to 1871 (Washburn Kershaw 1944-45) revealed that only 9.3\% (25/ 268) contained details of the place of origin of the interred. This is probably because most of those buried would have originated from an earlier wave of settlers in the seventeenth and eighteenth centuries and the connection to their original homeplace would have weakened by the nineteenth century. In contrast, some $61.2 \%(85 / 139)$ of contemporary memorials in Yard One at St. Patrick's Cemetery contain details of the place of origin of the deceased or, in the case of young children not ascribed a place of origin themselves, that of their parents $(n=3$, with the Phelan memorial of 1835 listing two counties). It should be noted that in among the Irish, and excluded from the preceding counts, were the burials of a Canadian, William Moray of Newfoundland who died in 1838, and James Riden of England who died in 1849. Both individuals had IHS-inscribed Latin crosses with willow trees on their memorials and must have identified as Catholic. A further memorial of an individual of "non-Irish" origin was that erected by Patrick Coughlin (a native of Doneraile in County Cork) in memory of his son, John Coughlin "of Lowell" who died on December 7, 1849.

When the origins of the Irish being commemorated are scrutinized further it is evident that most individuals were connected to a particular county $(96.3 \% ; 79 / 82)$ and 
some 20 counties were represented. The greatest proportions of Irish had emigrated from Counties Cork $(20.3 \% ; 16 / 79)$, Kerry $(16.5 \% ; 13 / 79)$, Tyrone $(10.1 \% ; 8 / 79)$, Longford $(7.6 \% ; 6 / 79)$ and Roscommon $(6.3 \% ; 5 / 79)$. As anyone with knowledge of the internal organization of the Gaelic Athletic Association (GAA) will know, the native county was - and still is - an important means of self-identification within Irish society; it was certainly considered to be of enough importance for a stone carver to be paid to include it on the majority of these early memorials. In addition, some $63.4 \%$ $(52 / 82)$ of the Irish headstones contained even more precise information about the place of origin of the deceased, such as their native townland, town, parish, or barony. The inclusion of such detailed information about the homeplace of the deceased is clear evidence that the attachment to Ireland was still very strong and these early immigrants still viewed themselves as Irish, and were proud of the fact. The latest memorial to contain place of origin information amongst this corpus of slate memorials dates to 1854 and was that of 19-year-old William Day who hailed from County Waterford. Early signs of the transition to Irish-American identity, however, may be seen in the 1849 Coughlin memorial discussed above in which the father who erected the memorial connected himself to County Cork, but his son was referred to as "of Lowell."

\section{Verses/Prayers}

In keeping with the Catholic identity of the deceased a substantial proportion contained prayers $(40.3 \%$; 56/139). These generally conveyed the sentiment of resting in peace and various forms of words were used, including the Latin form (Requiescat in pace) $(96.4 \% ; 54 / 56)$. In the majority of cases the prayer was located at the end of the epitaph. A small number also, or only $(n=1)$, contained the phrase "Gloria in excelsis Deo" at the top of the memorial, usually following the curvature of the rounded top $(10.7 \%$; $6 / 56)$. Interestingly a number of memorials $(n=7)$ also included other verses from a range of hymns or poems that are perhaps less traditionally associated with Catholicism. As discussed above, the very early memorial for John Bork (died 1832) mirrored the Yankee format identically and only included a verse. This was an excerpt from a poem by English-born, Rev. John Lawson, a Baptist minister in Calcutta, written in 1820 following the death of his two children in 1819 (Anon 1827: 33) (see Fig. 2). In the remaining six cases the verses were associated with the more typically Catholic prayers discussed above.

\section{Language}

Ireland moved from an eighteenth-century bilingual position to become a largely monolingual English-speaking entity by the end of the nineteenth century. While it is true that the Great Famine greatly affected the lowest strata within society who were more likely to be monoglot Irish speakers, the rise of English as the primary language on the island had been well underway before that time. For men like Hugh and James Cummiskey the acquisition of English - the language of commerce and industrymust have been a key factor that enabled them to set off for Boston in 1817 and 1818 respectively. The migration experienced in the years following the economic downturn in the aftermath of the Napoleonic Wars in 1815 was of a "pull" nature, with the ablest and fittest opting to leave Ireland under their own volition to forge a new life for 
themselves in a place with greater opportunity than that offered by the tenanted farms of their homeland. This in turn led to chain migration, with oral history from the 1990s evidently suggesting the Cummiskeys were a key element in bringing out other hopeful young Irish people from Tyrone to work in Lowell (Donnelly and Allmond 2011: 4).

It is of interest that the slate headstones erected in St. Patrick's Cemetery during the period from 1832 to 1860 consistently opted for the use of the anglicized phonetical spellings of Gaelic Irish surnames and place names-be it Cummiskey (Mac Cumascaigh, derived from the personal name Cumascach, and meaning "the son of the confuser") or Dromore (Droim Mór, meaning "large ridge"). The advantage of being an English speaker was evidently recognized among the Irish in Lowell and there is not a single headstone in Yard One that contains a word as Gaeilge. That said, there are mangled phonetic anglicizations among the place names recorded on the headstones, such as "Arelough" which might be the townland of Ardlough in the outskirts of Derry City, but could equally be the townland of Orlock in County Down. This acts as a reminder that the process of formalization of the anglicized phonetic versions of Irish place names in Ireland was still an ongoing process at the time when the headstones were being erected in Lowell.

\section{Conclusions}

Grave memorials are a somewhat overlooked, but highly valuable, source of information concerning cultural identity (Mytum 2004: 11). This study has demonstrated the contribution they can make to studies of past migration, in this case in the context of the Irish diaspora. The slate headstones in Yard One of St. Patrick's Cemetery in Lowell provide insight into the mindset of an Irish migrant community in a new town in New England during the early to mid-nineteenth century. Reading the epitaphs we can appreciate the sense of loss of loved ones, but what is of particular note is the associated symbolism on the headstones which acted as an expression of this community's religious beliefs, and their evident continued attachment to Ireland as their place of origin. This public display of Catholic and Irish identity is all the more remarkable when we consider that strong anti-Catholic and anti-Irish forces were at play within Massachusetts at this time, as expressed through events such as the destruction of the Ursuline Convent in Boston by a Yankee mob in 1834, and the Broad Street Riot in Boston on July 11, 1837 (O’Connor 1998: 48). Lowell was not immune from such community strife. A failed attempt by Yankees was made on May 17-18, 1831, to destroy St. Patrick's Church, then under construction (O’Dwyer 1920: 15-18), while in May 1835 St. Patrick's Cemetery was vandalized and wooden crosses, marking the graves of the dead, were wrenched from the ground and broken up (McKean 2018: 18). This latter incident highlights that evidently not all of the Irish could afford fine headstones for their departed loved ones. The existence of the memorials included in this study, however, indicates that some members of the community were financially able and were in the process of establishing themselves as a respectable Irish middle class within the town, engaged in property, trading, and construction works. This is exemplified by Hugh Cummiskey, elected as a town constable with Samuel Murray in April 1832 and - although a former owner of a brewery in 
Charlestown - someone who took the temperance pledge in 1840 and ceased selling alcohol from his West Indies store on Merrimack Street (Anon 1840: 122).

From an early stage there appears to have been confidence among Lowell's Irish community regarding their place in the developing town, to the extent that by the $1830 \mathrm{~s}$ they felt able to express their identity for all to see on St. Patrick's Day each year. First celebrated in Lowell in 1833 (McKean 2018: 16-18), by 1841 an annual parade was being held, although it evidently caused some Yankee hostility, as can be judged by the fact that a newspaper report from 1843 related how a stuffed effigy of St. Patrick was placed on Lowell Street on the route of the parade "for the purpose of insulting our Irish citizens" (McKean 2018: 28). For the Irish in Lowell, however, "the St. Patrick's Day parades, as they wound through the city streets, promoted an awareness that it was they, the Irish, who had built the city, and it was they who continued to maintain it" (Marston 1991: 226). Until 1868 the St. Patrick's Day parade and the membership of its participants were strictly controlled by the conservative Irish Benevolent Society who were intent on promoting an image of respectability, but also one of community strength. "Both the parade participants as well as the crowds that gathered along the route demonstrated the presence of an Irish community that was a social and political force to be reckoned with" (Marston 1991: 219). The Irish did have numerical strength; from the small groups of laborers who had arrived in East Chelmsford in the early nineteenth century, by 1855 the Irish comprised $28 \%$ of Lowell's 37,553 inhabitants and that percentage rose to nearly half the town's population in the years after the Civil War (Marston 1988: 418). Their evident desire for recognition of their respectability also helps explain the publication of the lady subscriber's article in the Lowell Morning Times in 1886 contributed to the newspaper in response to a perceived slight - real or otherwise - contained in comments made by C. C. Chase in a public address which made mention of the huts in which the Irish dwelt during the early years of Lowell's development. The article highlighted that the pioneering families in 1819 had originated from good stock in Ireland, and were descended from families with land, who were intelligent and industrious. While they may have been forced to dwell in temporary housing in their first years in Lowell, they "built better houses more in accordance with those they had been accustomed to, as their means increased" (Anon 1886: 1). Those who came after them to work on the excavation of the canals were "men of skill, education and character, whose descendants have occupied prominent places in the city's history. They have been skilled mechanics, successful merchants, legislators, soldiers, priests and professional men" (Anon 1886: 1).

The occurrence of shamrocks carved on the slate headstones at St. Patrick's Cemetery is another example of the Irish expressing their identity and ethnicity, both among themselves but also to their Yankee neighbors. Ethnicity is self-defined rather than inherited and the ethnic markers of immigrant groups can often differ quite markedly from traditions in both the native and new countries. As discussed above, the use of shamrocks as a symbol of Ireland had occurred since at least the late seventeenth century and its use was on the increase during the nineteenth century. The ubiquitous Celtic Cross headstone bedecked in shamrocks, however, is a tradition that developed across Ireland - and among the Irish diaspora — only during the later nineteenth century (Mytum 2004: 145). This was also the situation for the appearance of carved shamrocks on public memorials such as those for Daniel O'Connell (unveiled 1882) and Charles Stewart Parnell (unveiled 1911), both located on O'Connell Street in Dublin (Nelson 1991: 105). It is not the case, therefore, that the use of shamrocks to decorate 
headstones was a tradition that came across to Massachusetts with the Irish during the first decades of the nineteenth century. Furthermore, it does not appear to be the case that similar shamrock-decorated headstones are to be found elsewhere in contemporary New England, even within Catholic cemeteries associated with the Irish, such as those of St. Augustine's in South Boston (opened in 1818) or Bunker Hill Roman Catholic Cemetery, Charlestown (opened around 1830); these are headstones both unique and specific to Lowell.

Brighton (2004: 153) has written about the material manifestations of the Irish diaspora, based on slogans and emblems found on artifacts such as clay tobacco pipes recovered from Irish immigrant sites in the United States. These objects can illustrate the materialization of both Irish nationality and heritage while also demonstrating political and social connection and solidarity with Ireland. Brighton noted that the symbolism displayed on a pipe bowl can publicly communicate a person's social or political position. You do not have to self-identify as Irish, however, to smoke a pipe decorated with shamrocks. In contrast, to have shamrocks - a recognized symbol of Ireland-carved on the headstone of a loved one is to purposely convey a very powerful ethnic message. Through an analysis of the memorials, however, it is also possible to see a gradual shift in the association with Ireland to an attachment to Lowell as the nineteenth century progressed, noticeably among the new generation, born and raised in Lowell and who had never been to Ireland. While their Catholicism was not in doubt, and they were evidently of Irish ancestry, they were beginning to identify as Americans, albeit of a hyphenated variety. We can see the commencement of this process in the inscription on the slate headstone that Patrick Coughlin, a native of "Donerail" [Doneraile] in County Cork, erected in memory of his son John, who had died on December 7, 1849, aged 21 years, where it was stated that he was "of Lowell." If the headstone is being read correctly, this suggests that John was born in Lowell around 1828. As such, he was one of the first generation of American-born Irish in the town.

It is unfortunate to note that none of the 21 "shamrock" stones can be assigned to a specific stone carver. As noted above, Benjamin Day had a workshop in Lowell from at least the mid-1820s through to his death in 1855 and it is tempting to see the stones as his craftwork. Regardless of who was responsible, however, it is evident they had no issues with the inclusion of Irish and Roman Catholic symbolism on their memorials, despite the evident tensions that existed in New England during these decades. Change was afoot, however, and the slate headstone tradition was coming to an end across Massachusetts in the face of the increased use of marble by the middle of the century. Both slate and marble had been used since the earliest years of St. Patrick's Cemetery, as exemplified by the small marble headstone belonging to Samuel Murray, Hugh Cummiskey's friend (died 1835), or the plain marble headstones of Ann Moran (died 1841) and James McCarthy (died 1845). By the 1850s marble memorials began to predominate, however, with the latest slate headstones belonging to Susan McCort (died 1851), Dennis Desmond (died 1851), David Barry (died 1853), John Gorman (died 1853), and William Day (died 1853), each decorated with a willow and a Latin Cross and IHS monogram, and Margaret Cummings (died 1853) and Elizabeth Fitzsimons (died 1854), both with headstones decorated solely by weeping willows. The end of the tradition came in 1860, with the last known slate headstone erected in the cemetery to commemorate two babies of the Moore family-Thomas (died 
August 27, aged eight months and seven days) and Ellen (died November 23, aged five months and six days).

The slate headstones at St. Patrick's Cemetery are a visible expression of the process of cultural negotiation that took place among Lowell's Irish community during the early history of their town and attest to the important contribution that grave memorials can make to studies of migration. The memorials selected by the Irish to commemorate their dead - and the stone carvers they employed to create the headstones - represent the newcomers' interaction with an established and respectable Yankee tradition. The Irish in Lowell were integrating themselves within their new environment, but they were evidently remaining visible as Irish and Catholic amid their host community. The circumstances whereby this came about relate to a convergence of factors. First, there was the pre-existing slate headstone tradition in the region serviced by highly skilled Yankee craftworkers who were willing to produce memorials for the Irish that included details and symbols that expressed the latter group's identity within an established medium. Second, there was a level of prosperity among elements of the Irish community as a middle class evolved in the new town, which chimed with a desire to invest in established concepts and expressions of respectability then in vogue among the host Yankee community. Third, was the confidence among the Irish that they belonged at the heart of Lowell society and had the strength of numbers required to publicly display their identity regardless of any threat of hostility, real or imaginary. The marriage of Yankee willows and urns with IHS monograms, Latin crosses and shamrocks on the slate headstones at St Patrick's Cemetery, however, also represent a powerful visual expression of something new that was being created in the United States as the nineteenth century progressed: the Irish-American.

Acknowledgments We are grateful to Victoria Denoon and Professor Frank Talty, formerly co-directors of the Center for Irish Partnerships, UMASS Lowell, for their support of this research, and to Walter Hickey for all his help in tracking down the article by the "lady subscriber" from the Lowell Morning Times in 1886. We are indebted to Libby Mulqueeny, Archaeology and Palaeoecology, Queen's University Belfast, for her help with the illustrations and, in particular, for producing the beautiful drawings of the shamrock headstones.

Open Access This article is licensed under a Creative Commons Attribution 4.0 International License, which permits use, sharing, adaptation, distribution and reproduction in any medium or format, as long as you give appropriate credit to the original author(s) and the source, provide a link to the Creative Commons licence, and indicate if changes were made. The images or other third party material in this article are included in the article's Creative Commons licence, unless indicated otherwise in a credit line to the material. If material is not included in the article's Creative Commons licence and your intended use is not permitted by statutory regulation or exceeds the permitted use, you will need to obtain permission directly from the copyright holder. To view a copy of this licence, visit http://creativecommons.org/licenses/by/4.0/.

\section{References}

Anon. (1827). Memoir of Rev. John Lawson, late missionary in Bengal, and pastor of the Baptist Church, Circular Road, Calcutta. American Baptist Magazine 1: 5-11 and continued in 2: 33-37.

Anon. (1840). The great obstacle. Journal of the American Temperance Union 4: 122.

Anon. (1886). Early Lowell. Reminisces of the first Irish families that came. Who there were, why they came, and what they did. Lowell Morning Times, April 19, 1886: 1.

Anon. (1933). Saint Patrick's Cemetery, Lowell, Massachusetts: Annual Bulletin for Lot Holders. Privately published, Lowell. 
Brighton, S. (2004). Symbols, myth-making and identity: The red hand of Ulster in late nineteenth-century Paterson, New Jersey. International Journal of Historical Archaeology 8: 149-164.

Bryce, I. B. D. and Roberts, A. (1993). Post-reformation Catholic houses of north-east Scotland. Proceedings of the Society of Antiquaries of Scotland 123: 363-372.

Cunliffe, C. (2017). Eighteenth-century "refugee camp" located in East Galway. Archaeology Ireland 31: 4.

Day, M. (2005). Benjamin Day, Stone Carver, Lowell, Mass. 1783-1855. http://www.pelhamnhhistory. org/library/pdffiles/day/benjaminday.pdf, accessed September 2014.

Dethlefsen, E. and Deetz, J. (1966). Death's heads, cherubs, and willow trees: experimental archaeology in colonial cemeteries. American Antiquity 31: 502-510.

Donnelly, C. and Allmond, G. (2011). The Cummiskeys of Crossan, parish of Kilskeery, county Tyrone. Directory of Irish Family History Research 34: 4-5.

Dublin, T. (1992). Lowell: The Story of an Industrial City. National Park Service, Washington, DC.

Fitzgerald, P. and Lambkin, B. (2008). Migration in Irish History, 1607-2007. Palgrave Macmillan, London.

Goodwin, C. L. (1992). Mourning Glory: The Story of the Lowell Cemetery. Lowell Historical Society, Lowell.

Green, J. O. (1887). Autobiography of Dr John O. Green. Contributions of the Old Residents' Historical Association 3: 217-242.

Linden, B. M. G. (1980). The willow tree and urn motif: changing ideas about death and nature. Markers $\mathbf{1}$ : $149-158$.

Marston, S. (1988). Neighborhood and politics: Irish ethnicity in nineteenth century Lowell, Massachusetts. Annals of the Association of American Geographers 78: 414-432.

Marston, S. (1991). Contested territory: an ethnic parade as symbolic resistance. In Weible, R. (ed.), The Continuing Revolution: A History of Lowell, Massachusetts. Lowell Historical Society, Lowell, pp. 213229.

McCaughey, M. (1992). Come Listen a While. R and S Printers, Monaghan.

McKean, D. D. (1997). The Cross and the Shamrock: The Art and History of St. Patrick Cemetery, Lowell, MA. Archives of St. Patrick's Parish, Lowell.

McKean, D. D. (2016). Lowell Irish. History Press, Charleston.

McKean, D. D. (2018). The Days that Went Before Us: Stories and Accounts of Lowell's Early Irish. Privately published, Lowell.

Mitchell, B. C. (1988). The Paddy Camps: The Irish of Lowell 1821-61. University of Illinois Press, Urbana. Mytum, H. (2004). Mortuary Monuments and Burial Grounds of the Historic Period. Kluwer Academic / Plenum, New York.

Nelson, C. (1991). Shamrock: Botany and History of an Irish Myth. Boethius Press, Kilkenny.

Nourse, H. S. (1894). History of the Town of Harvard, Massachusetts, 1732-1893. Warren Hapgood, Harvard.

O'Connor, T. (1998). Boston Catholics: A History of the Church and its People. Northeastern University Press, Boston.

O'Dwyer, G. F. (1920). The Irish Catholic Genesis of Lowell. Sullivan Brothers, Lowell.

Seasholes, N. S. (2003). Gaining Ground: A History of Landmaking in Boston. MIT Press, Cambridge, MA.

Washburn Kershaw, L. (1944-1945). Tombstone Inscriptions of Lowell, Massachusetts. Genealogical Records of Molly Varnum Chapter, Daughters of the American Revolution.

Publisher's Note Springer Nature remains neutral with regard to jurisdictional claims in published maps and institutional affiliations. 